\title{
Association between Personal Attributes of Farmers with their Adoption of Tomato Production Technology in Jashpur District, Chhattisgarh (India)
}

\author{
Lokesh Kumar Tinde ${ }^{1 *}$, Arbind Kumar Sai ${ }^{2}$, R.K. Doharey ${ }^{2}$ and R.K. Kushwaha ${ }^{3}$
}

${ }^{1}$ Department of Agricultural Extension, Bidhan Chandra Krishi Viswavidyalaya, Mohanpur, District-Nadia, West Bengal-741252, India

${ }^{2}$ Department of Extension Education, N.D. University of Agriculture and Technology, Kumarganj, Faizabad, Uttar Pradesh-224229, India

${ }^{3}$ Department of Agricultural Extension, Chandra Shekhar Azad University of Agriculture and Technology, Kanpur, Uttar Pradesh-208002, India

*Corresponding author

\section{A B S T R A C T}

The present study was conducted in Jashpur district of Chhattisgarh (India) during 2014-15 due to the important vegetable crops and commercial areas. Adoption of the tomato production technology is important for increasing the production level. Hence, this study

\section{Keywords}

Tomato, Adoption level, Innovativeness, Correlation, Chhattisgarh

\section{Article Info}

Accepted:

28 March 2018

Available Online:

10 April 2018 was conducted to know the adoption level and its relationship with personal and socioeconomical characteristics of tomato grower. Information was obtained with the help of personal interview method during the study period. The data were analyzed, tabulated and the results were drawn with the help of appropriate statistical methods like score, adoption index, mean score value, rank, standard deviation and correlation coefficient were calculated. The finding of the study revealed that the overall level of adoption of tomato production technology was medium. Majority of the farmers $(68 \%)$ had medium level of adoption of scientific tomato cultivation practices. More number of large farmers had high level of adoption as compared to medium and small farmers. The study also revealed that annual income, extension contact, innovativeness, economic motivation and knowledge were found highly significant and positive correlation with adoption of scientific tomato cultivation practices. Should be more awareness programs are organized to increase level of knowledge and adoption of tomato cultivation practices to sustain tomato production in Chhattisgarh.

\section{Introduction}

Tomato crop not only provides maximum output but also give more income per unit area of land to the farmers. Tomato (Lycopersicon esculentum Mill.) is an herbaceous fruiting plant. It originated in Latin America and has become one of the most widely grown vegetables with ability to survive in diverse environmental conditions (Rice et al., 1987). Fruits and vegetables reduce the demand on cereals and are one of the cheapest and richest sources of natural protective foods, contributing much needed proteins, carbohydrates, mineral, salts and vitamins in the human diet. There has been a significant 
and continuous increase in the domestic consumption of fruits and vegetables in our country owing to the general rise in consumer spending on food as a result of the increased per capita income. In the world total global area of tomato was 48.15 lakh hectors with production of $16302.05 \mathrm{MT}$ and productivity 33.9 MT in 2011-12 (FAO 2012-13). In India total area cultivated by tomato was 882.03 hectors with the production of $18735.91 \mathrm{MT}$ and productivity of $21.24 \mathrm{MT}$ in 2013-14. The world India share of tomato was $11.5 \%$ of the total tomato production in 2013-14 (NHM 2013-14). After potato and onion crops, production of tomato in India comes under third position, but ranks second after potato in the world (FAO 2012-13). The area increase from 907.05 hectors in 2011-12 and 882.03 ha in 2013-14, while in terms of production it has increased from 18653.3 MT in 2011-12 to 18735.9 MT in 2013-14 and productivity has increased from 20.56 quintals to 21.24 quintals yield/ha in the year of 2011-12 and 2013-14 in India. Major tomato growing leading states are A.P., Karnataka, M.P., Telangana, Orissa, Gujarat, M.H., W.B., Bihar, and Chhattisgarh. A.P. was 1st in position in the area and production, which was $28.63 \%$ from production while Chhattisgarh occupied the 10th position by $4.35 \%$ from production in India (NHB 2013-2014). This paper aims to following objectives- 1 . To find out the extent of adoption of scientific tomato cultivation practices by tomato growers. 2 . To study the relationship between selected independent variables and the extent of adoption of scientific tomato cultivation practices.

\section{Materials and Methods}

The study was purposefully conducted in Jashpur district of Chhattisgarh due to the important vegetable crops and commercial areas. Five villages were randomly selected from one block making 106 villages covered in this study. From each village, 20 respondents randomly selected, making a sample of 100 respondents. The primary data were collected with the help of the personal interview method during the study period.

The data were analyzed, tabulated and the results were drawn with the help of appropriate statistical methods like score, mean score value, standard deviation and correlation coefficient were calculated.

\section{Results and Discussion}

Adoption extent of farmers about scientific tomato cultivation practices: The adoption extent among farmers about scientific tomato cultivation practices was analyzed and 32 practices and 11 groups were delineated for the study. Practice wise distribution of the respondents on the basis of adoption extent about scientific cultivation practices is presented in Table 1.

The data in (Table 1) indicates that the average, adoption extent of recommended scientific tomato cultivation practices were 24.79 per cent. Out of 11 selected practices, the extent of adoption of Harvesting, marketing and storage, $75.66 \%$ was higher than the other adopted practices of tomato and it was ranked $1^{\text {st }}$ followed by the adoption of plant protection measures and time of sowing, $49.86 \%, 38.33 \%$ and were ranked $2^{\text {nd }}$ and $3^{\text {rd }}$, respectively. The extent of adoption of the recommended scientific tomato cultivation practices like high yielding varieties (HYVs), $29.66 \%$, field preparation $26.66 \%$ and plant growth regulators $15.76 \%$ and were ranked $4^{\text {th }}, 5^{\text {th }}$ and $6^{\text {th }}$, respectively. While the extent adoption of recommended scientific tomato cultivation practices likes seed rate and recommended spacing, irrigation management and inter cropping and weed management, with $14.9 \%, 14.66 \%$ and $5.33 \%$ and were ranked $7^{\text {th }}, 8^{\text {th }}$ and $9^{\text {th }}$, respectively. 
Table.1 Distribution of tomato growers according to adoption of tomato production technology

\begin{tabular}{|c|l|c|c|}
\hline \multirow{2}{*}{ S. N. } & \multicolumn{1}{|c|}{ Cultivation practices } & \multicolumn{2}{c|}{ Respondents } \\
\cline { 3 - 4 } & & Percentage & Rank \\
\hline 1. & Field Preparation & 26.66 & V \\
\hline 2. & High yielding Varieties (HYVs) & 29.66 & IV \\
\hline 3. & Seed Treatments & 38.33 & XI \\
\hline 4. & Time of sowing & 14.90 & III \\
\hline 5. & Seed rate and recommended spacing & 1.97 & VII \\
\hline 6. & Fertilizers application & 15.75 & X \\
\hline 7. & Plant growth regulators & 14.66 & VI \\
\hline 8. & Irrigation management & 5.33 & VIII \\
\hline 9. & Inter cropping and weed management & 49.86 & IX \\
\hline 10. & Plant protection measures & 75.66 & II \\
\hline 11. & Harvesting, marketing and storage & $\mathbf{2 4 . 7 9}$ & I \\
\hline & Total average & & \\
\hline
\end{tabular}

Table.2 Overall adoption $\left(\mathrm{Y}_{1}\right)$ extent of farmers about scientific tomato cultivation practices

\begin{tabular}{|c|c|c|c|} 
S. N. & $\begin{array}{c}|c| \\
\text { Overall adoption Categories } \\
\text { (Scores) }\end{array}$ & Number & Percentage \\
\hline 1. & Low (Up to 18) & 13 & 13.00 \\
\hline 2. & Medium (19-36) & 68 & 68.00 \\
\hline 3. & High (Above 36) & 19 & 19.00 \\
\hline & Total & $\mathbf{1 0 0}$ & $\mathbf{1 0 0 . 0 0}$ \\
\hline
\end{tabular}

Mean=26.93, S.D. $=9.12$, Min. $=10.62$, Max. $=50.52$

Table.3 Relationship between independent variables and adoption of scientific tomato cultivation practices

\begin{tabular}{|c|l|c|}
\hline S. No. & Variables & Correlation Coefficient $(r)$ \\
\hline 1. & (X1) Housing pattern & $0.2558^{*}$ \\
\hline 2. & (X2) Land Holding & -0.0844 \\
\hline 3. & (X3) Annual Income & $0.64571^{* *}$ \\
\hline 4. & (X4) Extension Contact & $0.7701^{* *}$ \\
\hline 5. & (X5) Innovativeness & $0.3736^{* *}$ \\
\hline 6. & (X6) Economic Motivation & $0.4255^{* *}$ \\
\hline 7. & (X7) Scientific Orientation & -0.0135 \\
\hline 8. & (8) Knowledge & $0.8644^{*}$ \\
\hline
\end{tabular}

$*$ Significant at $5 \%$ and $1 \%$ and probability level 0.195 and 0.254 respectively. 
Fig.1 Practice wise adoption extent of farmers about scientific tomato cultivation practices

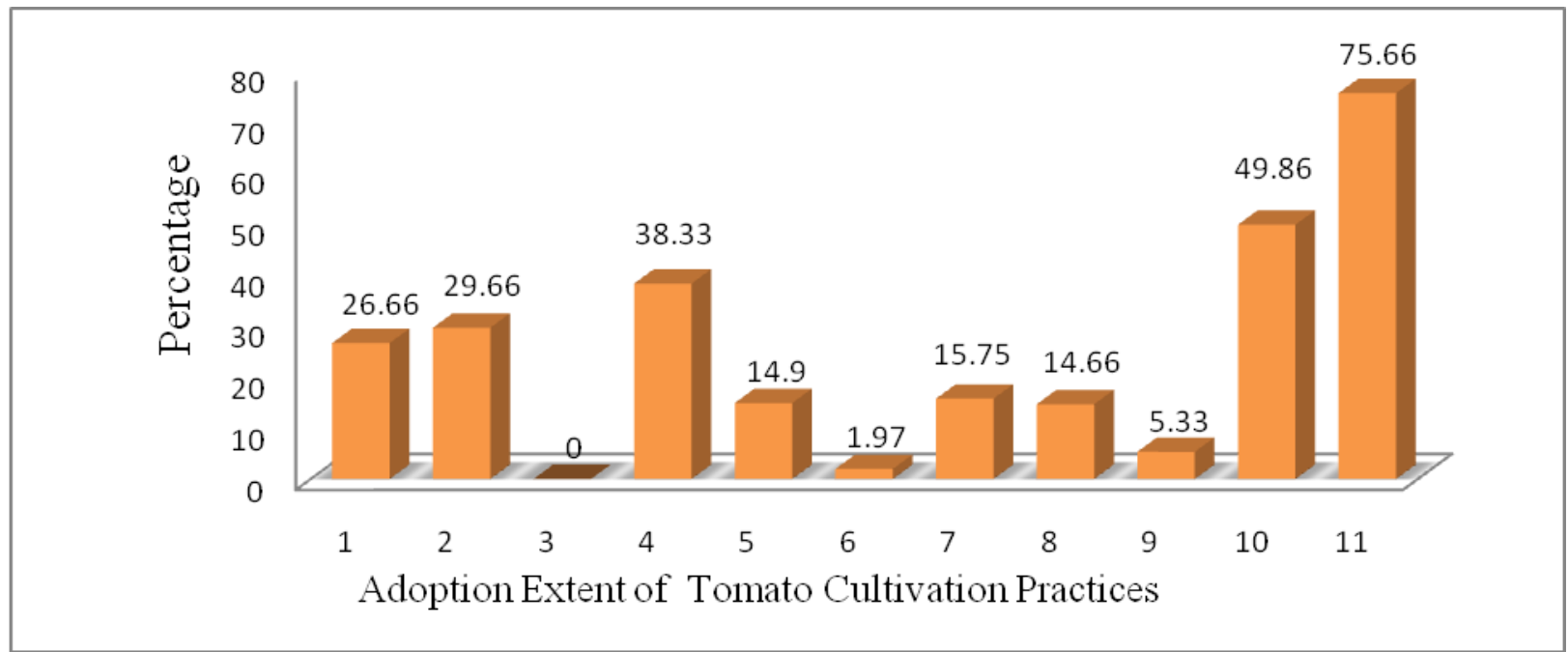

Further, the adoption extent of recommended scientific tomato cultivation practices likes, fertilizers application and Seed treatment with $1.97 \%$ and $00.00 \%$ and was ranked $10^{\text {th }}$ and $11^{\text {th }}$, respectively (Fig. 1).

\section{Overall adoption extent}

The Data in (Table 2) indicated that 68 percent respondents comes under medium and 19 percent respondent comes under high adoption categories and remaining 13 percent respondent's adoption level is low about scientific tomato cultivation practices respectively.

\section{Relationship between independent variables and adoption of scientific tomato cultivation practices}

The data in Table 3 showed that out of eight selected independent variables, only five variables i.e. annual income, extension contact, innovativeness, economic motivation and knowledge were found highly significantly and positively correlated with the extent of adoption about scientific tomato cultivation practices. Therefore, as it is clear from the obtained results, if the values of the variables increase the adoption extent of scientific tomato cultivation practices will also be increase. Further, the variable like annual income, extension contact, innovativeness, economic motivation and knowledge were found highly significant and positive correlation with adoption of scientific tomato cultivation practices. Those variables, which showed the significant and positive relationship, had direct influence over adoption extent about scientific tomato cultivation practices. Further, the variables like housing pattern were found significant and positive correlated with adoption extent. The variables like land holding and scientific orientation were found non-significant and negatively correlation with adoption extent of scientific tomato cultivation practices. It can be concluded from this study that great majority 68 percent of the tomato grower had medium to high level of adoption regarding scientific tomato cultivation practices. The degree of attitude of respondents was observed significant with housing pattern, while it was highly significant with annual income, extension contact, innovativeness, economic motivation, and knowledge. It was found non-significant with land holding and scientific orientation. The finding of this 
study indicated that knowledge of improved practices of tomato cultivation contributed significantly to the prediction of the adoption of the small farmers. The extension agencies have to play an important role to create awareness among the farmers about scientific tomato cultivation practices. Extension agencies should demonstrate to the farmers the process of seed treatment and keep them updated about recent HYVs. Extension agencies should also impart the technical knowhow of balanced use of fertilizer. Government should ensure farmers timely availability of quality seeds and procurement of farm produce at reasonable price. Thus, there is urgent need to increase the adoption of recommended tomato production technology, through proper utilization of sources of information, extension contact, exhibition and training programs should be conducted in different aspects of tomato production by concerned agencies. If the level of knowledge of tomato growers regarding recommended tomato production technology is expanded, the extent of adoption will be increased.

\section{Acknowledgements}

The authors hereby acknowledge the improvement brought about in this paper due to the valuable comments of editors and referee.

\section{References}

FAOSTAT (2012) February 2015 (Data for 2012, 2013 N/A) and for India Data -
(Data for 2013-14) Department of Agriculture and Cooperation. (www.fao.org.in).

Jaitawat, V. S. and Sharma, K. D. (2008). Association on between levels of knowledge of cultivators regarding recommended cumin cultivation technology and selected independent variables. Indian Journal of Social Research, 49:83-92.

Jat, J. R., Singh, S., Lal, H. and Choudhary, L. R. (2012). Knowledge level of farmers about improved tomato production technology. Rajasthan Journal of Extension Education.20:159163.

Nagar, S. N. (2006). "Knowledge and adoption of recommended coriander cultivation technology among the farmers of Atru tehsil in Barandistrict of Rajasthan”. M.Sc. (Ag.) Thesis, MPUAT, Udaipur, Bikaner (Raj.), India.

NHM (2013) Indian Horticulture Database2014 (Data for 2013-14). National Horticulture Board, Gurgaon (Haryana). Department of Agriculture and Cooperation, Pp.177.

Rice R.P., Rice L.W. and Tindall H.D. (1987). Fruit and Vegetable Production in Africa. Macmillan Publishers, U. K., pp. 371.

Sasane, G. K., Jagdale, U. D. and Khule, R. P. (2010). Knowledge and adoption of brinjal management practices by the farmers Agriculture Update; 5(3/4): 495-497.

\section{How to cite this article:}

Lokesh Kumar Tinde, Arbind Kumar Sai, R.K. Doharey and Kushwaha, R.K. 2018. Association between Personal Attributes of Farmers with their Adoption of Tomato Production Technology in Jashpur District, Chhattisgarh (India). Int.J.Curr.Microbiol.App.Sci. 7(04): 3394-3398. doi: https://doi.org/10.20546/ijcmas.2018.704.383 